DOI: $10.19195 / 0137-1150.167 .2$

\author{
NINA OSIPOVA
}

Вятский государственный университет, Rosja

\title{
Смех и смерть \\ в русской культурной традиции: истоки и трансформация мотива
}

\begin{abstract}
Жизнь в ее целом никогда не принимает смерти всерьез.

Она смеется, пляшет и играет, она строит, собирает и любит перед лицом смерти.
\end{abstract}

Рабиндранат Тагор ${ }^{1}$

Справедливо утверждение, что специфика культуры постигается по её отношению к смерти. В славянской (в том числе и русской) культурной традиции смерть и отношение к ней - предмет особого осмысления. Проблема смеха и смерти в антропологическом ключе, сформировавшись в научном пространстве еще в начале XX века, в последние годы она вновь приобрела интерес в новых контекстах — как в контексте смеховой культуры, так и в психологическом аспекте. Это заметно даже на уровне последних научных мероприятий и спецвыпусков, обсуждающих данную проблематику ${ }^{2}$.

Традиционно в исследованиях Клода Леви-Строса, Елеазара Мелетинского, Ольги Фрейденберг, Вячеслава Иванова и других обозначен феномен бинарности в осмыслении отношения человека к смерти, заключающийся в том, что „смех и слезы - это метафоры смерти в двух её фазах - возрождения и умирания..."3. Причем О. Фрейденберг аргументирует тезис о том, что скорбное, умирающее божество, которое радостно оживает в преисподней - это влага, питающая землю. Лингвистические выводы также

${ }^{1}$ Мудрость Востока, сост. А. Ю. Кожевников, Москва 2013, с. 92.

2 Конференция в Мюнхене: Танатология, танатопоэтика, „смерть поэтов”, „, поэты смерти" (2006); Смех и плач в традиционной культуре (2016); специальный выпуск международного журнала „Эйдос” — Танатос и культура 2016, № 1.

3 О. М. Фрейденберг, Миф и литература древности, Москва 1998, с. 117. 
фиксируют названные смыслы, в частности Марк Маковский устанавливает семантическую близость слов „смеяться” и „смерть” в разных языках 4 . Значимую роль сыграли исследования, соотносящие смех с исторической типологией культур 5 .

Танатология в контексте русской смеховой культуры модулировалась известной работой Михаила Бахтина, специальными исследованиями фольклористов и антропологов (Владимир Пропп, Наталья Велецкая, Ольга Седакова, Татьяна Бернштам), объединяющих мортальный и смеховой дискурсы в ритуально-обрядовых и фольклорных текстах. В календарных ритуалах переход к новым формам культа предков, как показала Н. Велецкая, воплощается в погребении знака самой смерти (для болгарской и русской культур характерны игры в покойников как театрализованная символизация погребения самой смерти). Исследователи устанавливают сходство оргиастических действ (смех, хмель, музыка, танцы) практически у всех славян и некоторых неславянских народов. Все формы символизации смерти сопровождались ритуальным весельем, основным элементом которого является смех 6 .

Данный ритуал - совершенно естественное соединение похорон и веселого пиршества для развлечения покойника (плачи и вопли чередовались с бурной оргией и пьянством). Эти элементы инвертировались и в праздничном контексте (сожжение в Купалу чучела Мары с притворным плачем), на что обращает внимание и В. Пропп, отмечая, что

в русских праздниках [...] момент растерзания, утопления и сожжения сопровождается ликованием, весельем, смехом и фарсовыми действиями [...]. Никакого празднования воскресения в русских обрядах и праздниках нет. Праздник состоит не в воскресении, а в умерщвлении ${ }^{7}$.

Татьяна Бернштам и Александр Козинцев вводят эту проблематику в более широкую чувственно-эмоциональную сферу ${ }^{8}$.

Мы отойдем от семантики плача, потому что плач сопровождает не только смерть как явление (хотя эти понятия - плач и смех - как правило, образуют антиномичную пару). В качестве иллюстрации можно привести пример тризны, состоящей из пира, плясок и воинских состязаний. В рус-

${ }^{4}$ М. М. Маковский, Образ мира и миры образов: Сравнительный словарь мифологической символики в индоевропейских языках, Москва 1991, с. 300-310.

5 Л. С. Седов, Типология культур по критерию отношения к смерти, „Синтаксис” 1989, № 2, с. 159-192; С. К. Лащенко, Заклятие смехом: Опыт истолкования языческих ритуалов восточных славян, Москва 2006.

${ }^{6}$ См.: А. Котляревский, О погребальных обычаях у языческих славян, Москва 1868.

${ }^{7}$ В. Я. Пропп, Русские аграрные праздники, Ленинград 1963, с. 95.

8 Т. А. Бернштам, Феномен ,смех-плач” в русской народно-православной культуре, [в:] Христианство в регионах мира, вып. 2, отв. ред. Т. А. Бернштам, А. И. Терюков, СанктПетербург 2008, с. 298-376; А. Г. Козинцев, Феномен „смех-плач” о различии сходного, „Антропологический форум” 2010, № 13, с. 117-124. 
ских летописях уже встречается соотнесенность тризны и пира (рассказ летописца о мести Ольги). А в Стоглаве о русских славянах читаем:

В троицкую субботу по селам и по погостам сходятся мужи и жены на жальниках и плачутся по гробам умерших с великим воплем. И егда скоморохи учнут играти во всякие бесовские игры, и они, от плача преставше, начнут скакати и плясати, и в долони бити, и песни сотонинские пети, на тех же жальниках обманьщики и мошенники 9 .

Позже, с развитием христианства, тризна стала синонимом поминок, утратив смеховой регистр. В таком же контексте фиксируется похоронный обряд молодых, который оформляется как свадьба, а позже переносится на похороны вообще. Большое распространение получили свадебная и „покойницкая” игры. Облаченного в саван „мертвеца” укладывали на доски или салазки и с воем и плачем вносили в избу. Присутствующих заставляли „прощаться” с ним. У мнимого покойника были огромные зубы, вырезанные из картофелины или репы. Похоронная процессия включала и „причт” — „попа” в рогоже с „кадилом” — горшком с куриным пометом; дьякона, певчих. В конце игры „покойник” оживал и убегал, пугая присутствующих. Виктор Гусев справедливо указал на генетические связи русских святочных игр в покойника с древнеславянскими похоронными обрядами и культом предков ${ }^{10}$. Однако постепенно магические функции были утрачены, и все действо превратилось в веселое представление. Похожие ритуалы описывают Ольга Седакова и Ежи Бартминьский ${ }^{11}$. Все данные, приводимые исследователями, свидетельствуют о типологической общности отношения славянских культур к смерти, специфика которого заключается в приятии смерти как необходимости или игнорировании её через изгнание из повседневности. Царство смерти - это царство, где нет смеха для живых, но есть хохот смерти (сказочная нечисть всегда хохочет). Это демонстрируют русские сказки, которые в данном контексте становились уже предметом исследования ${ }^{12}$.

Но при этом если в западноевропейском карнавальном сознании (и Михаил Бахтин это доказывает) смех - это преодоление страха смерти, то в русском сознании смех „сосуществует” со страхом смерти, являя интересный феномен „прирученной” смерти. Именно поэтому такой смех стихиен и опасен (,смеяться, когда нельзя”, по выражению Марины Цветаевой). Но

${ }^{9}$ В. К. Соколова, Весенне-летние календарные обряды русских, украинщев и белорусов, Москва 1979, с. 213.

${ }^{10}$ В. Е. Гусев, От обряда к народному театру (эволюция святочных игр в покойника), [в:] Фольклор и этнография. Обряды и обрядовый фольклор, отв. ред. Б. Н. Путилов, Ленинград 1974, с. 49-59.

11 О. А. Седакова, Поэтика обряда - Погребальная обрядность восточных и южных славян, Москва 2004; Е. Бартминьский, Языковой образ мира: очерки по этнолингвистике, пер. автора, Москва 2005 (J. Bartmiński, Językowe podstawy obrazu świata, Lublin, 2007).

12 См.: А. В. Малинов, Образ смерти в русской сказке, „ВЕЧЕ. Журнал русской философии и культуры” 1995, № 3, с. 163-178. 
нас интересуют не все проявления мортального дискурса, а лишь связанные со смеховым. Смех сотнеен со сказочным представлением о смерти вообще, которая „снимается” в веселье, в феномене „антиповедения”. Доказательство тому - уникальный памятник XIII века Духовное завещзание Елистрата Шибаева. ${ }^{13}$.

Русская культура не знала карнавала в бахтинском понимании, прежде всего потому, что смех в ней сохранял свою лиминальную сущность, не разрушая мир, а сохраняя связь с ним. Этот аспект в полной мере проявился в мортально-смеховом дискурсе русской литературы ${ }^{14}$. Классический пример мы находим в одном из лучших рассказов Ивана Бунина Весельй двор (1911):

Егор, глядя в гроб, крестился размашисто и часто. Он играл ту роль, что полагалась ему у гроба матери. Он моргал, будто готовый заплакать, кланялся низко, наклоняя капающую свечку, крепко зажатую в его култышке. Но далеко были его мысли, и, как всегда, в два ряда шли они. Смутно думал он о том, что вот жизнь его переломилась - началась какая-то иная, теперь уже совсем свободная. Думал и о том, как будет он обедать на могиле — не спеша и с толком...

Так и сделал он, засыпав мать землею: ел и пил до отвала. А под вечер, тут же, у могилы, плясал, всем на потеху, - нелепо вывертывал лапти, бросал картуз наземь и хихикал, ломал дурака, напился так жестоко, что чуть не скончался $[. . .]^{15}$.

Кстати, распространенный у ряда народов (в том числе и славянских) погребальный обычай предполагал инсценировку свадьбы на похоронах. В изложении Александра Котляревского описывается, как вдова в подвенечном платье сопровождала умершего до могилы, где исполняла танец невесты, который вместе с пищей, напитками, музыкой является символом свободы покойника. Инсценированный разгул, как и в целом веселье на похоронах, играет особую роль магической силы, которая должна была способствовать усилению производительных сил природы, новое возвращение к жизни ${ }^{16}$. Возможно, когда-то фраза „весело, как на кладбище” не воспринималась как ирония.

Думается, что именно поэтому русская культура впоследствии расширила игровой принцип соотношения смеха и смерти. Об этом свидетельствует характер персонификации Смерти в русских сказках, которая не воспринимается больше в пародийном виде. Персонифицруясь в образе смешной старухи, глуповатого Водяного, она одновременно принимает и жуткие формы в виде вурдалаков, мертвецов, которые в подсознании при-

13 Духовное завещание Елистрата Шибаева, [в:] Записки отдела рукописей Государственной библиотеки СССР им. В. И. Ленина, вып. 17, Москва 1955, с. 154-156.

${ }_{14}$ Р. Л. Красильников, Танатологические мотивы в художественной литературе, Москва 2015.

15 И. А. Бунин, Веселый двор, [в:] его же, Полное собрание сочинений в шести томах, т. 5, Петроград 1915, с. 311.

16 А. А. Котляревский, О погребальных обычаях у языческих славян, Москва 1868. 
званы „снимать” страх смерти. В повести об Анике-воине Смерть — „тощая, сухая, кости голые! И несет в руках серп, косу, грабли и заступ”17. Баба-Яга из другой русской сказки — „костяная нога, нос в потолок врос, сопли через порог висят, титьки на крюку замотаны..."18. Сказочная Смерть часто глуповато-доверчивая, падкая на угощение. Её легко обмануть, что и делает солдат в многочисленных быличках. В украинской и белорусской традиции сценки о казаках, обманувших смерть, разыгрывались в Вертепах, распространившихся и на Русь. В отличие от западноевропейской практики, где смерть ассоциируется со скелетом, в славянских сказках она неоднозначна (одновременно смерть - символ страха, мудрости, милосердия и даже простоты и наивности - Цыган и смерть, Казак и смерть, Солдат и Смерть, Москаль и смерть). В некотором смысле Смерть выступала в сказках в роли Трикстера, этакого „провокатора”, без которого невозможна победа культурного героя над силами зла.

Театральная культура Руси закрепила эту модель персонифицированной смерти в её комическом варианте. Так, среди персонажей театра Петрушки был и один самый зловещий, который побеждал главного героя. Это была Смерть, которая после словесной перепалки забирала Петрушку с собой. Однако герой неизбежно воскресал в другом пространстве, демонстрируя закон вечного обновления. Данное обстоятельство привело к тому, что некоторые исследователи стали находить связь между Петрушкой и языческими божествами, которые бесконечно умирали и возрождались ${ }^{19}$.

Впоследствии уже в литературном творчестве в жанре сатирических памфлетов, сатирической эпитафии разовьется смеховой элемент, элиминирующий древнюю традицию. Как образно сказал Осип Мандельштам, христианство „эллинизировало смерть”, т. е. перевело её из архаическоязыческого уровня на антропологический.

В ходе развития русской культуры специфика соотношения понятий „смех-смерть” органично вписалась в историко-культурную ситуацию РусиРоссии, связанную с кровавыми событиями, тиранией, политической жизнью, на этом фоне усиливая свою амбивалентную природу. Существует мнение, что это было связано только с преодолением страха перед смертью, но это не совсем так, потому что в наблюдаемых нами артефактах в паре „смех-смерть” доминирует все-таки смех. Пример: знаменитый лубок Как мыши кота хоронили, который в разное время трансформировался в соответствии с новой по-

17 А. Н. Афанасьев, Славянские колдуны и их свита, Москва 2014, с. 248.

${ }^{18}$ Царевна-лягушка, [в:] Гуси-лебеди. Фольклор для детей от кольбельных до былин, сост. В. И. Калугин, Москва 1990, с. 214.

19 См. об этом: О. В. Цехновицер, Театр Петрушки, Москва-Ленинград 1927; А. Алферов, Петрушка и его предки, [в:] Десять чтений о литературе, Москва 1895; А. П. Кулиш, Петрушка — «лицо неразгаданное, мифическое»: к вопросу о генезисе героя народной уличной кукольной комедии, [в:] В профессиональной школе кукольника, вып. III, Ленинград 1987, c. $132-138$. 
литической ситуацией (от варианта басни Эзопа в XVII веке до политической сатиры на Ленина и меньшевиков из карикатуры начала XX века).

Еще один важный аспект мортально-смехового дискурса - это его героическая ипостась: смех перед лицом смерти знаменует победу над врагом (мотив отчетливо звучавший еще в Житии протопопа Аввакума, 1672). Смех жертвы - это своеобразное послание, с одной стороны, обстоятельствам, палачу, с другой - самому себе. Такой смех демонстрирует не только собственную нравственную силу в трагических обстоятельствах, но и слабость противника. Когда положение становится неразрешимым, смех воспринимается как способ поведения жертвы. Нельзя не согласиться здесь с мыслью Дмитрия Лихачева, что в русской культуре „ободрение смехом в самый патетический момент смертельной угрозы всегда было сугубо национальным явлением"20. Как не вспомнить здесь ставшую легендой историю с пирушкой декабристов накануне восстания и реплику: „Ах, умрем! Как славно мы умрем!", приписываемую, по разным данным, Кондратию Рылееву или Матвею Муравьеву-Апостолу. Немного в ином контексте, но в русле этой же традиции, представлены такие противоположные образы, как хохочущая голова старухи из сна Раскольникова, смех горьковского Данко, который в конце пути ,посмотрел на свободную землю и засмеялся гордо. А потом упал и умер" 21 , смех в поэме Евгения Евтушенко Братская ГЭС (1965) (сцена казни Стеньки Разина: „[...] и, жестоко, не скрывая торжества, над царем захохотала голова!"22).

Примечательно, что в связи с интересом к западноевропейскому фольклору и средневековью, увлечением игровыми моделями культуры обе ветви отношения смеха и смерти объединились в культуре конца XIX и первой половины XX века. Театрально-игровая культура Серебряного века перевела игру со смертью в своеобразную кентаврическую модель карнавальной стихии, плясок смерти и русской фольклорно-балаганной традиции. В эпицентре этих тенденций оказались практически все литературно-художественные течения России - от символизма до авангарда.

Образцом подобного синтеза можно назвать Победу смерти (1907) Федора Сологуба, Веселую смерть (1908) Николая Евреинова, Смерть грешника и праведника, то есть прение Живота со Смертью (1907) Алексея Ремизова, Ошибку Смерти (1915) Велимира Хлебникова.

В Оиибке Смерти культурная модель „пляски смерти” западноевропейского средневекового карнавала встраивается в модель русского ярмарочного кода и христианскую модель тайной вечери. Действие происходит

20 Д. С. Лихачев, А. М. Панченко, Н. В. Понырко, Смех в Древней Руси, Ленинград 1984, c. 61 .

${ }^{21}$ М. Горький, Старуха Изергиль, [в:] его же, Полное собрание сочинений. Художественные произведения в двадиати пяти томах, т. 1, Москва 1968, с. 96.

22 Е. А. Евтушенко, Братская ГЭС, http://philosofiya.ru/kazn_stenki_razina.html [дата обращения: 3.10.2017]. 
в „харчевне”, где мертвецы во главе с Барышней смертью (хозяйкой харчевни ,веселых мертвецов-трупов”) водят хороводы, поют, пьют, играют на разных инструментах и веселятся на „балу смерти”.

В пьесе прослеживаются не только культурные традиции западноевропейской и русской культур, но и многочисленные интертекстуальные переклички, большей частью опосредованные: и dance macabre вкупе с песнями вагантов, и мистика романтической баллады в духе Эдгара По, Вильгельма Гауфа, Василия Жуковского, Александра Пушкина, и эксплицитные образы символистской драмы (в частности вариации „клюквенного сока” из блоковского Балаганчика (1906)).

Глумливо-кощунственное ёрничанье соседствует в пьесе с гротеском в духе фольклорной традиции: тринадцатый гость обращается со Смертью примерно так же, как солдат в русской сказке со Смертью, пьеса насыщена разговорными интонациями, балаганными ритмами, „буффонными” образами, стихией ярмарочного веселья в соединении с мистическим ужасом.

Связь русской балаганной стилистики с традициями Commedia del'Arte демонстрирует и Молчаливая Смерть в пьесе Николая Евреинова Веселая Cмерть, где она представлена двойником Коломбины (в этом смысле она близка Деве с косой из Балаганчика Александра Блока): „[...] ярко-белый скелет в прозрачном, дымчатом платье фасона Коломбины, на черепе такая же треуголка"23. Несмотря на пристрастие автора к итальянской комедии масок, в пьесе последовательно отражается и русское отношение к смеху. По собственному утверждению автора, смерть представлена в виде балаганной героини, что доказывает театрально-сценическую природу мортальных сюжетов („Между ламбрекеном балагана и погребального катафалка, - иронизировал драматург, - разница только в цвете" ${ }^{24}$ ), их игровую сущность, о чем свидетельствуют и наблюдения зарубежных исследователей о русском театре этого времени ${ }^{25}$.

Обозначенная тенденция, сформировавшаяся в творчестве символистов, получила дальнейшее развитие в литературе авангарда, в частности обериутов, которые, смеясь над смертью, утверждали абсолютную свободу в несвободном мире, тем переводя смерть в систему социокультурных маркеров человеческих и общественных отношений.

При этом, формально вписываясь в эстетику черного юмора или пляски в кругу мортальных сюжетов, в обилии встречающихся и в западноевропейском искусстве, творчество обериутов экстраполировало эстетику „черного юмора” в сферу общественно-философских проблем.

${ }^{23}$ Н. Евреинов, Веселая смерть, [в:] его же, Драматические сочинения в трех томах, т. 2, Санкт-Петербург 1914, с. 89.

${ }^{24}$ Н. Евреинов, Демон театральности, http://itexts.net/avtor-nikolay-nikolaevich-evreinov/ 167926-demon-teatralnosti-nikolay-evreinov/read/page-8.html [дата обращения: 30.09.2017].

25 См.: J. D. Clayton, Pierrot in Petrograd: Commedia dell'arte in Twentieth-Century Russian Theatre and Drama, Montreal-Kingston-London-Buffalo 1993. 
Катастрофичность и трагический абсурд жизни (именно это и демонстрирует русский авангард в ситуации „сдвига”) сопровождается перверсивной иронией по отношению к смерти. Искушение (1929) Николая Заболоцкого, Ёлка у Ивановых (1938) и Священный полет цветов (1931) Александра Введенского, Сундук (1937), Случай (1936), Грязная личность (1937), Смерть старичка (1935-1936), Страшная смерть (1935), Реабилитация (1940) и другие рассказы Даниила Хармса отличаются не просто фамильярным отношением к смерти, но и жутковатым осмыслением господствующей системы ценностей. Но при этом характерный „трупный физиологизм" на грани бреда - это дань не западноевропейской, а, скоpee, русской балаганной традиции, где, как уже упоминалось, страшное и смешное не отделены друг от друга.

Именно потому, что черный юмор в западноевропейской традиции развивался по пути визуализации (переместившись в анимацию, комиксы, кинематограф - комиксы Вильгельма Буша, например), а в русском варианте - по пути вербализации, он приобрел в творчестве русского авангарда особую значимость, подготовив почву для последующих экспериментов театра абсурда и постмодернистской литературы в их отношении смерти. В то же время это не традиционный черный юмор, потому что любой юмор (даже если он черный) все-таки предполагает наличие объекта юмора или эмоциональное отношение субъекта к происходящему. У Хармса же смерть не вызывает какой-либо эмоциональной реакции; она утрачивает свой сакральный смысл, переходит из мира человека в мир вещей, она — „никакая”, она то, что потом назовут симулякром в духе постмодернистской ироний.

Одной из интересных тенденций, продолжающих традицию черного юмора в русской культуре, являются садистские стишки (т. н. садюшки), переосмысливающие штампы официальной поэзии и вызванные прежде всего социальными причинами.

Садистские стишки давно стали особым жанром советского (и уже постсоветского) детского фольклора, сформировавшегося на фоне традиционных частушек, стихотворных пародий и анекдотов, а также детских страшилок. Исследователи полагают, что возникновение садистских стишков было связано с зашкаливающим сознание официозом, пропагандистской идеологией и прямолинейной дидактически-воспитательной литературой, вызывающей отторжение - не случайно в этих стишках основная роль в трагических событиях принадлежит членам семьи. Циничный, глумливый и кощунственный смех - смех юродивого - сопряжен в садюшках одновременно с тягой к страху и преодолением страха (смешно и страшно), именно здесь русская культура ближе всего осознает свои истоки юродства ${ }^{26}$.

${ }^{26}$ Одна из обстоятельных и глубоких работ на эту тему: М. Лурье, Садистский стишок в контексте городской фольклорной традииии: детское и взрослое, общее и специфическое, „Антропологический форум” 2007, № 6, с. 287-309. 
Сконцентрировав в себе основные формулы и универсальные мотивы народного фольклора, садистские стишки создали модель текста, очень удобную для передачи множества смыслов: „Тихо плещется вода в стенках унитаза / Вспоминайте иногда Васю-водолаза”; „Мальчик в конверт запечатал тротил, / Папе на письменный стол положил. / Сын на граните решил написать: / Нечего было за двойку ругать"27.

По одной версии, в современном виде этот жанр создал Игорь Мальский, который со своими однокурсниками по Ленинградскому университету организовал „Коммуну имени Жёлтой Подводной Лодки” - впоследствии один из самых известных центров культуры хиппи. Согласно другой версии, автором первой стихотворной страшилки был Олег Григорьев (,Я спросил электрика Петрова: - Для чего ты намотал на шею провод? / Петров мне ничего не отвечает, / Висит и только ботами качает"28).

Несмотря на то, что в 90-е годы XX века жанр утратил свою популярность, до сих пор в сети по-прежнему „гуляют” не только „классические” садюшки, но и новые - плод Интернет-творчества. Своеобразие их заключается в том, что, как и обериутские творения, они не апеллируют к первоначальной природе смеха, а адресованы интеллектуальному слою читателей.

Интересно, что специфика русской национальной смеховой культуры по отношению к смерти, скрытая разными слоями культуры, просматривается в её современных отголосках. Так, известно, что такая сфера современного фольклора, как анекдот, наиболее последовательно сохраняет ментальное содержание культуры, ориентируясь на национальную её специфику. В своем стремлении создать противоположную систему ценностей анекдот объединяет смертный и смеховой миры и инвертирует их, как это мы наблюдаем в фольклоре. Не случайно в анекдоте в наибольшей степени обнажены истоки мортального юмора, игры со смертью в самом широком смысле - смертью человека, его страданий, социальных институтов, души и тела... Он опрокидывает в смех то, что в общепринятом смысле является слишком серьёзным и жутким.

Анекдот реагирует на ситуации, связанные с неудовлетворительным состоянием транспорта, туристическим обслуживанием, плохой медициной, сложными семейными отношениями, политическими реалиями - со всем тем, что может провоцировать смерть. Пример тому - многочисленные подборки анекдотов о смерти в Интернет-сети.

Сравнительное исследование мортально-смехового дискурса в разных национальных культурах позволит не только проследить вектор трансформации танатологических мотивов в сознании человека, но и описать механизм этой трансформации, восходящий к мифологическим моделям

27 „Мальчик в овраге нашел пулемет...” Страшилки - антология черного юмора, сост. А. Р. Ярось и А. Н. Наумов, Минск 1993, http://modernlib.ru/books/yumora_antologiya/ malchik_v_ovrage_nashel_pulemet/ [дата обращения: 1.10.2017].

28 Там же. 
древности, снимающим оппозицию „жизнь-смерть”. И не случайно именно XX век с его социальными и военными катастрофами, экологическими проблемами, в следующем столетии расширил пространство „веселой смерти" как способа самосохранения личности, преодоления страха и бессилия человека на фоне эсхатологических ожиданий и прогнозов.

\section{Библиография}

Алферов А., Петрушка и его предки, [в:] Десять чтений о литературе, Москва 1895.

Бартминьский Е., Языковой образ мира: очерки по этнолингвистике, Москва 2005.

Бернштам Т. А., Феномен „смех-плач” в русской народно-православной культуре, [в:] Христианство в регионах мира, вып. 2, отв. ред. Т. А. Бернштам, А. И. Терюков, СанктПетербург 2008.

Бунин И. А., Веселый двор, [в:] его же, Полное собрание сочинений в шести томах, т. 5, Петроград 1915.

Горький М., Старуха Изергиль, [в:] его же, Полное собрание сочинений. Художественные произведения в двадияати пяти томах, т. 1, Москва 1968.

Гусев В. Е., От обряда к народному театру (эволючия святочных игр в покойника), [в:] Фольклор и этнография. Обряды и обрядовый фольклор, отв. ред. Б. Н. Путилов, Ленинград 1974.

Гуси-лебеди. Фольклор для детей от кольбельных до былин, сост. В. И. Калугин, Москва 1990.

Духовное завещание Елистрата Шибаева, [в:] Записки отдела рукописей Государственной библиотеки СССР им. В. И. Ленина, вып. 17, Москва1955.

Евреинов Н. Н., Веселая смерть, [в:] его же, Драматические сочинения в трех томах, т. 2, Санкт-Петербург 1914.

Евреинов Н., Демон театральности, http://itexts.net/avtor-nikolay-nikolaevich-evreinov/167926demon-teatralnosti-nikolay-evreinov/read/page-8.html [дата обращения: 30.09.2017].

Евтушенко Е. А., Братская ГЭС, http://philosofiya.ru/kazn_stenki_razina.html [дата обращения: 03.10.2017].

Козинцев А. Г., Феномен „смех-плач” о различии сходного, „Антропологический форум” 2010, № 13.

Котляревский А., О погребальных обычаях у языческих славян, Москва 1868.

Красильников Р. Л., Танатологические мотивы в художественной литературе, Москва 2015.

Кулиш А. П., Петрушка - «лицо неразгаданное, мифическое»: к вопросу о генезисе героя народной уличной кукольной комедии, [в:] В профессиональной школе кукольника, вып. III, Ленинград 1987.

Лащенко С. К., Заклятие смехом: Опыт истолкования языческих ритуалов восточных славян, Москва 2006.

Лихачев Д. С., Панченко А. М., Понырко Н. В., Смех в Древней Руси, Ленинград 1984.

Лурье М., Садистский стишок в контексте городской фольклорной традиции: детское и взрослое, общее и специффическое, „Антропологический форум” 2007, № 6 .

Маковский М. М., Образ мира и миры образов: Сравнительный словарь мифологической символики в индоевропейских языках, Москва 1991.

Малинов А. В., Образ смерти в русской сказке, „ВЕЧЕ. Журнал русской философии и культуры” 1995, № 3. 
„Мальчик в овраге нашел пулемет”. Страшилки - антология черного юмора, сост. А. Р. Ярось и А. Н. Наумов, Минск 1993, http://modernlib.ru/books/yumora_antologiya/malchik_v_ ovrage_nashel_pulemet/ [дата обращения: 1.10.2017].

Мудрость Востока, сост. А. Ю. Кожевников, Москва 2013.

Пропп В. Я., Русские аграрные праздники, Ленинград 1963.

Седакова О. А., Поэтика обряда - Погребальная обрядность восточных и южных славян, Москва 2004.

Седов Л. С., Типология культур по критерию отношения к смерти, „Синтаксис” 1989, № 2.

Соколова В. К., Весенне-летние календарные обряды русских, украинцев и белорусов, Москва 1979.

Фрейденберг О. М., Миф и литература древности, Москва 1998.

Цехновицер О. В., Театр Петрушки, Москва-Ленинград 1927.

Clayton J. D., Pierrot in Petrograd: Commedia dell'arte in Twentieth-Century Russian Theatre and Drama, Montreal-Kingston-London-Buffalo 1993.

\section{Laughter and death in Russian cultural tradition: Origins and transformation of the motive}

\section{Summary}

The author studies the mythological basis of attitude to death in the Russian national culture of laughter, the role of ritual laughter in folklore and post-folklore, and various ways of its presentation in Russian literature. Special attention is paid to the component of the game in Russian rituals, and to laughter in Russian fairy tales.

The balance of laughter and death in Russian and, moreover, the Slavic world view is connected with its liminality, i.e. with the situation of transition and "on the border". The article analyzes the transformation of different features of laughter as a means of overcoming death, as well as the way to create irony and absurd in the modern "mortal" discourse regarding ritual tradition. In symbolism and avant-garde literature of A. Blok, N. Evreinov, F. Sologub, D. Kharms, V. Khlebnikov etc. laughter is considered as a means of overcoming the absurd of death. This literature synthesizes the western model of "dance of death" into Russian folklore and buffoon tradition. In contemporary Russian literature it performs a genre-forming role (jokes about death, "sadistic rhymes" etc.).

Keywords: Russian culture, death archetype, laughter as death overcoming, irony and parody in folklore and literature

\section{Сміх і смерть у російській культурній традиції: витоки і трансформація мотиву}

У статті розглядається міфологічна основа відношення до смерті в російській національній сміховій культурі, простежується роль ритуального сміху в фольклорі і постфольклорі, різних формах його художньої репрезентації в літературі. Спеціальна увага приділяється ігровому компоненту в обрядовому комплексі російської культури, специфіці сміхової репрезентації в російських чарівних казках. Специфіка співвідношення сміху і смерті в російській (i, шир- 
ше, слов'янській) картині світу пов’язана $з$ його лімінальністю, тобто з ситуацією переходу, положення «на кордоні».

Аналізується трансформація характеристик сміху як подолання смерті, способу створення авторської іронії і абсурду в сучасному мортальному дискурсі в його зв'язках з ритуальною традицією.

Сміх сприймається як подолання абсурду смерті в літературі символізму і авангарду (О. Блок, М. Євреїнов, Ф. Сологуб, Д. Хармс, В. Хлєбніков), яка синтезує західноєвропейську модель «танці смерті» і російську фольклорно-балаганну традицію. В сучасній російській літературі вона виконує жанроутворюючу роль (комічні анекдоти про смерть, «садистські віршики»).

Ключові слова: російська культура, архетип смерті, сміх як подолання смерті, іронія і пародія смерті в фольклорі та літературі 